\title{
Beta-Hemolytic Streptococcus
}

National Cancer Institute

\section{Source}

National Cancer Institute. Beta-Hemolytic Streptococcus. NCI Thesaurus. Code C86190.

A bacterium that is assigned to the genus Streptococcus that is able to facilitate the complete rupturing of red blood cells, thus producing wide, clear, zones around colonies on blood ag ar plates. 